\title{
Digestibility, Milk Yields, and Milk Quality of Ettawa Crossbred Goats Fed Coleus amboinicus L. Leaf Extract
}

\author{
M. Afdal ${ }^{a, b, *}$, D. Darlis ${ }^{a}$, \& A. Adriania ${ }^{a, b}$ \\ ${ }^{a}$ Faculty of Animal Husbandry, Jambi University \\ ${ }^{\mathrm{b}}$ Center of Excellence - Sustainable Integrated Farming System, Jambi University \\ Kampus Pinang Masak Mandalo Darat KM 15 Jambi 36361 Indonesia \\ *Corresponding author: m.afdal@unja.ac.id \\ (Received 05-09-2020; Revised 20-04-2021; Accepted 11-05-2021)
}

\begin{abstract}
Coleus amboinicus L. leaf (CAL) could reduce the rate of amino acid deamination and protein degradation within the rumen. This phenomenon would hopefully increase the amount of protein that passes through the rumen to the abomasum. Therefore, it might improve the digestibility of the ration and then influence the milk yield and quality. The objective of this experiment was to evaluate the effect of extracted CAL within the ration on the ration digestibility, milk yield, and milk quality of Ettawa crossbred (EC) goats. This study used sixteen EC with an average weight of $32.25 \pm 3.31 \mathrm{~kg}$ and aged 1.5-2.5 years. Experimental goats were fed diets with different CAL extracts: $P_{0^{\prime}} 0 \%$ (control); $P 1$, $2 \%$ powdered CAL; $\mathrm{P} 2,2 \%$ ethanol-extracted CAL; and $\mathrm{P}_{3}, 2 \%$ water-extracted CAL. The experiment was conducted in a randomized block design with four replication blocks. All variables were statistically analyzed with ANOVA and significances were followed by Duncan's test. $P_{3}$ treatment significantly $(p<0.05)$ increased milk yield and milk quality in comparison with control. Unlike the other treatments, $P_{3}$ treatment was water-extracted CAL that could affect these variables. $P_{3}$ treatment showed the best result among the four treatments. In conclusion, $P_{3}$ treatment, the supplementation of $2 \%$ waterextracted CAL within the ration, could improve the milk yield up to $30.24 \%$ in comparison with the control ration and also improve milk composition, such as milk protein $(4.47 \%)$, milk casein $(3.99 \%)$, milk fat $(3.85 \%)$, and solid nonfat (SNF) $(6.53 \%)$. The supplementation of water-extracted CAL within ration could improve the milk yield and milk quality of EC.
\end{abstract}

Keywords: Coleus amboinicus; digestibility; Ettawa crossbred; milk yields

\section{INTRODUCTION}

There have been some efforts to improve the milk yields of Ettawa crossbred (EC) goats. Acharya et al. (2015) and Dharmawan et al. (2019) have modified the ration composition to increase milk yields. Djoković et al. (2015) tried to use hormone therapy to accelerate the growth of the mammary gland during pregnancy and Resthu et al. (2019) studied the effect of oxytocin induction on the milk chemical composition of EC milk in Aceh, Indonesia. Other studies have aimed to improve nutrient intake (Marwah et al., 2010) and nutrient digestibility (Arief et al., 2016) during pregnancy and lactation. However, the optimal method to improve the quantity and quality of milk is still uncertain, especially during early lactation in EC goats. For example, Arief et al. (2020) reported that the milk yield of EC goats was $0.84-1.23 \mathrm{~kg} / \mathrm{head} / \mathrm{d}$. Monica et al. (2014) reported a milk yield of local African goats from 1.01 to $2.71 \mathrm{~kg} /$ head/d in Kenya. In addition, goats are prolific animals and must provide sufficient quantities of breast milk for kids. Therefore, it is a good challenge to improve the productivity of dairy goats by manipulating feed intake, especially by utilizing local feed sources. Using extracts from Coleus amboinicus L leaf (CAL) within the ration fed to goats is one way to improve the milk yield.

In North Sumatra, mothers usually consume this leaf to increase the breast milk for their babies. This leaf contains lactogogue having an activity to stimulates the transports and absorptions of nutrients from the blood circulation into the secretory cells of the udder gland, a phenomenon that increases milk yield (Kent et al., 2012). In addition, CAL also contains antioxidant compounds that could serve to inhibit cancer growth (Laila et al., 2020). This leaf also contains high levels of potassium, which functions as a calming agent, a blood cleaner, and a pain reliever. Damanik (2009) reported that CAL leaf could enhance breast milk yields of mothers in North Sumatra while Adriani et al. (2019) added that CAL could improve the in vitro digestibility of dry matter (DM) and organic matter (OM). This outcome might be due to the effect of the active compound carvacrol, which can reduce the rate of amino acid deamination and protein degradation. Zamiri et al. (2015) stated that carvacrol mainly increased the ammonia concentration in the rumen and the nitrogen balance. Haro et al. 
(2018) stated that inhibition or reduction of the rate of amino acid deamination and protein degradation would reduce protein degradation in the rumen. Therefore, more protein could pass through the rumen and into the abomasum, from where it is absorbed. For example, the addition of 250 and $500 \mathrm{mg} / \mathrm{L}$ carvacrol within the ration could reduce protein degradation by $51.5 \%$ and $72.8 \%$, respectively (Garcia, 2007). Thus, the amount of undegradable protein increases in the rumen and also increases the absorption from the hindgut, a phenomenon that also increases the OM digestibility. Furthermore, Turkyılmaz et al. (2011) expected that galactogogue effect of CAL on phytoestrogen and estradiol 17ß hormone (E2), an endogenous estrogen, stimulated the proliferation of the mammary gland cells. This stimulation would increase the production of casein and the activity of enzyme lactose synthetase in the epithelial cells of the mammary gland. Overall, this would have an impact on DM digestibility and, subsequently, the milk yield, quality, and quantity.

The supplementation of CAL in ration could be applied in this study. There were many methods to be applied, such as feeding the animal in the form of CAL simplicial, ethanol extracted of CAL or water extracted of CAL. The preliminary study was done using $2 \%$ ethanol or water extracted from CAL. Based on the above information, this experiment examined the effect of supplementation of CAL extract in the ration fed to EC goats on their milk yields. It was expected that this study would provide the best treatments of CAL extract in the ration of EC on the ration digestibility, milk yield, and milk quality. The objective of this experiment was to evaluate the effect of extracted CAL within the ration on the ration digestibility, milk yield, and milk quality in EC goats.

\section{MATERIALS AND METHODS}

This experiment was conducted at Fostered Farmer Field, the University of Jambi for two months and chemical analysis was done at the Ruminant Laboratory of University of Jambi and Livestock Research Centre, Ciawi, Bogor, Indonesia. This experiment followed animal ethics and welfare compliance according to the general animal welfare provisions from Laws of The
Republic Indonesia Number 18 of 2009 about Livestock and Animal Health. The ethical clearance for health, Faculty of Medicine and Health Science, University of Jambi was issued a Letter of Ethical Clearance to run this project with the approved number of 284/UN21.8/ PT/2020.

\section{Sample Preparation}

Fresh CAL was ordered online through Tokopedia and imported from Bekasi, West Java, Indonesia. The sample of CAL was cleaned by using tap water to remove odd dirty material and drained. The samples were chopped into 2-cm-long pieces and indirectly sundried in a chamber covered with a black cloth until dry. The following day, the dry sample was ground through a 1.5 mm sieve to obtain a powder. The powder was then extracted with $96 \%$ ethanol and water following the procedure reported by Ahirwar \& Tembhre (2016) with slight modifications. For water extraction, the sample was put into a container with a 1:5 (CAL powder: distilled water) ratio and then boiled at $90^{\circ} \mathrm{C}$ for 20 minutes. The sample was soaked in $96 \%$ ethanol at room temperature for 3 days and then filtered for ethanol extraction. The solvent was then evaporated using a rotary evaporator. All extracts were stored at $4^{\circ} \mathrm{C}$ for further use.

\section{Animals and Feed}

Sixteen female EC goats, aged 1.5-2.5 years and $32.25 \pm 3.31 \mathrm{~kg}$, were used in this study after the second delivery and for around 1-1.5 months lactation. For medical care, each goat was treated with a worm tablet and vitamin $\mathrm{B}$ before the adaptation period. Each goat was grouped into four blocks based on weight for replication and randomly allotted into an individual pen previously sterilized with disinfectant.

Experimental goats were fed with the same ration containing fresh kumpe grass (Hymenachne amplexicaulis), rice bran, soya bean meal, coconut cake, and tofu waste (Table 1). Ration used in this study was estimated to have $17.64 \%$ crude protein (CP) and 3,352.5 kcal/kg ME and it was higher than the theoretical requirement of goat (15\% CP and 2,820 kcal/kg ME) (NRC, 1981).

Table 1. Ration composition of experimental goats

\begin{tabular}{|c|c|c|c|c|c|c|c|}
\hline \multirow{2}{*}{ Feed } & & \multirow{2}{*}{ Percentage } & \multicolumn{5}{|c|}{ Chemical component } \\
\hline & & & $\mathrm{ME}(\mathrm{kcal} / \mathrm{kg})$ & $\mathrm{DM}(\%)$ & CF $(\%)$ & EE (\%) & $\mathrm{CP}(\%)$ \\
\hline Kumpe grass & & 70 & 3,861 & 20.29 & 29.32 & 1.85 & 14.10 \\
\hline Rice bran & & 10 & 2,980 & 91 & 11.4 & 13 & 12.9 \\
\hline Soya bean meal & & 12 & 2,290 & 90 & 0.41 & 0.51 & 45 \\
\hline Coconut cake & & 5 & 1,540 & 100 & 12.1 & 10.2 & 21.6 \\
\hline \multirow[t]{4}{*}{ Tofu waste } & & 3 & 414 & 89.5 & 16.53 & 5.54 & 19.55 \\
\hline & & 100 & $3,352.5$ & 39.103 & 22.3182 & 3.1662 & 17.64 \\
\hline & \multicolumn{7}{|c|}{ Chemical component $(\%)$} \\
\hline & $\mathrm{DM}(\%)$ & Ash (\%) & WSE (\%) & ASE $(\%)$ & Saponin (\%) & Tannin $(\%)$ & Flavonoid (\%) \\
\hline CAL & 92.2 & 12.5 & 20.53 & 6.53 & 1.35 & 3.28 & 0.72 \\
\hline
\end{tabular}

Note: $\mathrm{WSE}=$ Water soluble extract; $\mathrm{ASE}=\mathrm{Al}$ cohol soluble extract; $\mathrm{ME}=$ metabolizable energy; $\mathrm{DM}=\mathrm{dry}$ matter; $\mathrm{CF}=\mathrm{crude}$ fiber; $\mathrm{EE}=\mathrm{ether}$ extract; $\mathrm{CP}=$ crude protein; CAL= Coleus amboinicus L. leaf. 
The amount of ration fed to each experimental goat was manually prepared as $100 \%$ of full consumption per goat per day. Each treatment of experimental ration was prepared by calculating the amount of feed provided and subtracted by the amount of feed refused from each experimental goat within $24 \mathrm{~h}$ during the pre-adaptation period. The treatment of $0 \% \operatorname{CAL}\left(\mathrm{P}_{0}\right), 2 \%$ powdered CAL $\left(\mathrm{P}_{1}\right), 2 \%$ ethanol-extracted CAL $\left(\mathrm{P}_{2}\right)$, or $2 \%$ waterextracted CAL $\left(\mathrm{P}_{3}\right)$ was prepared proportionally based on the initial weight of each experimental goat and mixed with concentrate to allow the goats to consume all CAL during the morning feeding. The composition of powder CAL can be seen in Table 1. The goats were fed with grass at 09.00 and 15.00. Moreover, there were 7 days of adaptation prior to 5 days of data collection.

\section{Digestibility}

The nutrient digestibility was assessed during 5 days of data collection. The conventional method of digestibility was applied by calculating the amount of ration input minus fecal output. Ration input was calculated as feed provided minus feed refused. The amount of ration provided and refused and fecal output was recorded at 08.00 in the morning during the data collection period. Ten percent of feed and fecal samples were sundried, oven-dried at $60^{\circ} \mathrm{C}$ overnight, ground in a $1 \mathrm{~mm}$ sieve, and stored at $4^{\circ} \mathrm{C}$ until further chemical analysis. These chemical analyses were used to calculate intake, the digestibility of DM, CP, crude fiber $(\mathrm{CF})$, acid detergent fiber (ADF), neutral detergent fiber (NDF), and hemicellulose.

\section{Milk Collection}

For milk collection, each goat was manually milked by hand at 07.00 and 16.00 for 5 days of sampling. The nipple was cleaned with $70 \%$ alcohol before milking to prevent microbial contamination. The milk was weighed and milk pH was measured soon after milking. Then, a $150 \mathrm{~mL}$ milk sample was separately poured into a cool container and transported to the Laboratory of the Faculty of Animal Husbandry, Jambi University, for further analysis. The specific gravity (SG) was measured by using a lactometer; milk fat was analyzed by following the technique reported by Gerber (1960). For SG, around $100 \mathrm{~mL}$ of fresh milk sample of every single treatment was prepared, filtered, and poured into a beaker glass at a temperature between $20-30{ }^{\circ} \mathrm{C}$. Then by holding the lactometer tip, it was inserted into the milk. The lactometer was allowed to float freely until it was at equilibrium. Immediately, a thermometer was put into the milk sample, and the milk's temperature was recorded (Tesfay et al., 2015). The SG of the milk was calculated by the following formula:

$\mathrm{SG}=(\mathrm{L} / 1000)+1$

where, L was the correction factor for recording lactometer at a given temperature, i.e., for every degree more than $60^{\circ} \mathrm{F}, 0.2$ was added to the lactometer reading, but for every degree less than $60^{\circ} \mathrm{F}, 0.2$ was subtracted from the lactometer reading.
The milk fat content was determined following the Gerber method (Tesfay et al., 2015). Ten milliliters of concentrated sulfuric acid (91\%-92\%) was pipetted into a butyrometer, and this acid was added with 11 $\mathrm{mL}$ of milk sample and mixed. Next, $1 \mathrm{~mL}$ of amyl alcohol was added to the butyrometer, closed with a lock stopper. Then the mixture was shaken and upturned several times until the acid completely digested the milk. Finally, the butyrometer was kept left in a water bath for 5 minutes at $65{ }^{\circ} \mathrm{C}$ and centrifuged in a Gerber centrifuge for 5 minutes. The butyrometer was placed in a water bath again at $65{ }^{\circ} \mathrm{C}$ for 5 minutes. In the end, the butyrometer reading was recorded.

Milk protein was analyzed by following the technique described by Rowland (1938). Ten milliliters of milk sample were poured into an Erlenmeyer Flask, then it was added with $20 \mathrm{~mL}$ of distilled water, 0.4 $\mathrm{mL}$ of concentrated Potassium Oxalate, and $1 \mathrm{~mL}$ of phenolphthalein indicator. Finally, the solution was left for around two minutes. The solution was titrated with $\mathrm{NaOH} 0.1 \mathrm{~N}$ until it was indicated with pink color. Next, $2 \mathrm{~mL}$ of formaldehyde (40\%) was added and re-titrated until it showed the pink color. The same procedure was done for the blank. The percentage of protein was calculated by using the following formula:

$\%$ Protein $=(p-q) m L \times 1.77$ (formol factor)

where $p$ is the volume of sample titration and $q$ is the volume of blank titration.

\section{Chemical Analysis}

Around $25 \mathrm{~g}$ of dry sample of feed, refusal, and feces collected during data collection was prepared to analyze DM, OM, CP, ether extract (EE), and CF by following the established analytical procedures (AOAC, 1990). For DM analysis, around one gram of sample was oven-dried at the temperature of $105{ }^{\circ} \mathrm{C}$ overnight and reweighted. The content of DM was calculated with the following formula:

$\mathrm{DM}=$ [Weight after oven-dried (g) / Weight before ovendried (g)] x $100 \%$

For OM analysis, the dry sample was then furnaced at $600{ }^{\circ} \mathrm{C}$ for $5 \mathrm{~h}$ and reweighted. The content of OM was calculated as $100 \%$ minus ash content in which ash with the formula below:

$\mathrm{OM}=\{[$ Weight before oven-dried $(\mathrm{g})$ - Weight after furnaced (g)] / Weight before oven-dried $(\mathrm{g})\} \mathrm{x}$ $100 \%$

For $\mathrm{CP}$ analysis, the sample was digested in a Kjeldahl tube with the following steps. Around one gram of sample was digested in boiling concentrated $\mathrm{H}_{2} \mathrm{SO}_{4}$ in a Kjeldahl tube to alter protein nitrogen to ammonia. Caustic was added to evaporate ammonia and ammonia produced was collected by distillation. The amount of ammonia collected by titration was measured. The percentage of nitrogen in the samples was calculated using the formula provided (AOAC, 1990).

For EE analysis, around ten grams of sample was extracted with hexane, fat solution, for 6 hours. Then 
the extract solution was distilled and the fat extract was oven-dried at temperature of $105{ }^{\circ} \mathrm{C}$, cooled, and weighted. The fat content was calculated by using the following formula:

Fat content $=[(\mathrm{A}-\mathrm{B}) / \mathrm{C}] \times 100 \%$

where $C$ was sample weight $(\mathrm{g})$, A was container weight before extraction $(\mathrm{g})$, and $\mathrm{B}$ was container weight after extraction $(g)$.

There are two steps for CF analysis. In the first step, the sample was extracted using $\mathrm{H}_{2} \mathrm{SO}_{4}$ on the boiling point for 30 minutes and filtered. Then the residue was added with $\mathrm{KOH}$ solvent and washed using acetone until completely neutral. The residue was oven-dried at $105^{\circ} \mathrm{C}$ and burned by the furnace at a temperature of $550{ }^{\circ} \mathrm{C}$ for three hours. The $\mathrm{CF}$ was calculated by using the following formula:

$\mathrm{CF}(\%)=[(\mathrm{A}-\mathrm{B}) / \mathrm{C}] \times 100$

where A was weight before drying, B was weight after drying, and C was sample weight.

NDF and ADF were analyzed by following the procedure of Van Soest (1963). For NDF analysis, half gram of sample (A) was put into a weighted crucible dish (B), added with $50 \mathrm{~mL}$ of neutral solvent and boiled for extraction for around one hour. After extraction, the mixture was vacuum-filtered and rinsed with hot water and finally rinsed with acetone (96\%). After that, the dish and sample were oven-dried at a temperature of $135^{\circ} \mathrm{C}$ for two hours, cooled into a desiccator, and weighted (C). The content of NDF was calculated by using the following formula:

$\operatorname{NDF}(100 \%)=[(C-B) / A] \times 100 \%$

For ADF analysis, half gram of sample (A) was put into a weighted crucible dish (B), added with $50 \mathrm{~mL}$ of acid solvent, and boiled for extraction for around one hour. After extraction, the mixture was vacuum-filtered and rinsed with acetone (96\%). After that, the dish and sample were oven-dried at a temperature of $135{ }^{\circ} \mathrm{C}$ for two hours, cooled into a desiccator, and weighted (C). The content of NDF was calculated by using the following formula:

$\% \operatorname{ADF}(100 \%)=[(\mathrm{C}-\mathrm{B}) / \mathrm{A}] \times 100 \%$

For Ca analysis, the ash sample was added with five milliliters of concentrated $\mathrm{HCl}$, diluted with distilled water, evaporated until $10 \mathrm{~mL}$ and poured into $100 \mathrm{~mL}$ beaker glass, rinsed with distilled water and shaken. Then around $20 \mathrm{~mL}$ of this mixture was put into Erlenmeyer glass and added with few drops of methylene red. Next, $\mathrm{NH}_{4} \mathrm{OH}$ was added until yellow color appeared and added with two drops of $\mathrm{HCl}$ until red color appeared. The mixture was boiled and added with $15 \mathrm{~mL}$ of ammonium oxalate, re-boiled until residue was formed. This residue was filtered with filter paper and rinsed with hot water until free acid and dried. Filter paper, including residue, was put into Erlenmeyer Flask containing $100 \mathrm{~mL}$ of distilled water and $5 \mathrm{~mL}$ of concentrated $\mathrm{H}_{2} \mathrm{SO}_{4}$ and boiled at a temperature of $70-80$
${ }^{\circ} \mathrm{C}$. Finally, it was titrated with $\mathrm{KMnO}_{4}$. The Ca content was calculated by using the following formula:

Ca content $(\%)=\left[\left(\mathrm{mL}\right.\right.$ titration $\left.\times \mathrm{N} \mathrm{KMnO}_{4} \times 1 / 2 \mathrm{AWCa}\right) /$ Sample weight $(\mathrm{mg})] \times 100 \%$

where AW was atomic weight.

For $\mathrm{P}$ analysis, the ash sample was added with 5 $\mathrm{mL}$ of concentrated $\mathrm{HCl}$ and kept leave for one hour and poured into a $10 \mathrm{~mL}$ volumetric flask and rinsed and shaken homogenously. One $\mathrm{mL}$ of this solution was transferred into 50-mL-cuvet and added with $3 \mathrm{cc}$ ammonium molybdate, 2.5 vitamin C solution, and distilled water, then shaken homogenously and wait for 30 minutes. Finally, the solution was read by a spectrophotometer at a wave length of 570 . The P content was calculated by using the following formula:

P content $(\%)=[($ Spectrophotometer read (absorbance) x $11.293+0.087)$ / Sample weight $(\mathrm{mg})]$ $\mathrm{x} 100 \%$

\section{Measured Variables}

The measured variables were 1) intakes of DM, $\mathrm{OM}, \mathrm{CP}, \mathrm{EE}, \mathrm{CF}$, energy, $\mathrm{Ca}$, and $\mathrm{P}$; 2) digestibility of DM, CP, CF, ADF, NDF, and hemicellulose; and 3) milk yield and milk quality factors including DM, protein, casein, fat, solids non fat (SNF), and SG.

\section{Experimental Design and Statistical Analysis}

This study was designed in a $4 \times 4$ randomized block design with four treatments $\left(\mathrm{P}_{0^{\prime}}, \mathrm{P}_{1^{\prime}}, \mathrm{P}_{2^{\prime}}\right.$ and $\left.\mathrm{P}_{3}\right)$ and four blocks for replication. All measured variables were statistically analyzed with ANOVA followed by Duncan's test for multiple comparisons (SAS, 2002).

\section{RESULTS}

\section{Nutrient Intake}

Table 2 presents nutrient intake in the experimental goats. The supplementation of extracted CAL in the ration did not affect the intakes of DM, OM, CP, EE, CF, $\mathrm{Ca}, \mathrm{P}$, and energy in the experimental goats.

\section{Nutrient Digestibility}

Table 3 presents the digestibility of DM, CF, CP, $\mathrm{ADF}, \mathrm{NDF}$, and hemicellulose in the experimental goats. The supplementation of extracted CAL in the ration did not affect nutrient digestibility.

\section{Milk Yield and Quality}

Table 4 presents the milk yield and quality parameters. There were significant differences $(p<0.05)$ in milk yield, milk protein, and milk casein and highly significant differences $(\mathrm{p}<0.01)$ in milk DM and SNF among the treatment groups. There were no differences in milk fat and SG among the groups. 
Table 2. The nutrient intake of Ettawa crossbreed goat fed with the addition of extracted Coleus amboinicus L. leaf in diet

\begin{tabular}{lcccc}
\hline \multirow{2}{*}{ Intake } & \multicolumn{3}{c}{ Treatments } \\
\cline { 2 - 5 } & $\mathrm{P}_{0}$ & $\mathrm{P}_{1}$ & $\mathrm{P}_{2}$ & $\mathrm{P}_{3}$ \\
\hline $\mathrm{DM}(\mathrm{g} / \mathrm{d})$ & $1,192.00 \pm 49.62$ & $1,245.72 \pm 6.34$ & $1,227.26 \pm 9.88$ & $1,232.30 \pm 62.49$ \\
$\mathrm{OM}(\mathrm{g} / \mathrm{d})$ & $1,071.22 \pm 44.51$ & $1,118.59 \pm 5.72$ & $1,101.98 \pm 17.87$ & $1,106.58 \pm 56.19$ \\
$\mathrm{CP}(\mathrm{g} / \mathrm{d})$ & $201.27 \pm 8.16$ & $210.27 \pm 1.18$ & $207.03 \pm 3.45$ & $208.09 \pm 10.87$ \\
$\mathrm{EE}(\mathrm{g} / \mathrm{d})$ & $43.25 \pm 2.26$ & $45.08 \pm 0.06$ & $44.69 \pm 0.50$ & $44.42 \pm 1.62$ \\
$\mathrm{CF}(\mathrm{g} / \mathrm{d})$ & $327.69 \pm 13.14$ & $342.27 \pm 1.98$ & $336.90 \pm 5.69$ & $338.77 \pm 17.94$ \\
$\mathrm{Ca}(\mathrm{g} / \mathrm{d})$ & $4.99 \pm 0.24$ & $5.21 \pm 0.01$ & $5.16 \pm 0.07$ & $5.15 \pm 0.22$ \\
$\mathrm{P}(\mathrm{g} / \mathrm{d})$ & $15.81 \pm 0.95$ & $16.45 \pm 0.06$ & $16.37 \pm 0.14$ & $16.17 \pm 0.51$ \\
Energy (kcal/kg DM) & $3,208.42 \pm 88.76$ & $3,365.31 \pm 11.45$ & $3,300.31 \pm 56.34$ & $3,263.42 \pm 61.91$ \\
\hline
\end{tabular}

Note: $\mathrm{DM}=$ dry matter; $\mathrm{OM}=$ organic matter; $\mathrm{CF}=$ crude fiber; $\mathrm{EE}=$ ether extract; $\mathrm{CP}=$ crude protein; $\mathrm{P}_{0}=$ treatment of $0 \%$ Coleus amboinicus $\mathrm{L}$. leaf $(\mathrm{CAL})$; $\mathrm{P}_{1}=$ treatment of $2 \%$ powdered CAL; $\mathrm{P}_{2}=$ treatment of $2 \%$ ethanol-extracted CAL; $\mathrm{P}_{3}=$ treatment of $2 \%$ water-extracted CAL.

Table 3. Digestibility of some nutrients within ration on Ettawa crossbreed goats (\%)

\begin{tabular}{lcccc}
\hline \multirow{2}{*}{ Digestibility (\%) } & \multicolumn{3}{c}{ Treatments } \\
\cline { 2 - 5 } & $\mathrm{P}_{0}$ & $\mathrm{P}_{1}$ & $\mathrm{P}_{2}$ & $\mathrm{P}_{3}$ \\
\hline DM & $67.57 \pm 2.43$ & $69.10 \pm 1.89$ & $67.85 \pm 2.50$ & $67.83 \pm 2.51$ \\
CP & $53.68 \pm 3.53$ & $55.81 \pm 2.59$ & $56.50 \pm 2.50$ & $56.91 \pm 1.80$ \\
CF & $30.73 \pm 7.45$ & $30.93 \pm 6.47$ & $30.42 \pm 6.46$ & $32.00 \pm 5.06$ \\
ADF & $72.06 \pm 1.32$ & $72.21 \pm 1.12$ & $72.00 \pm 1.23$ & $72.66 \pm 0.54$ \\
NDF & $74.02 \pm 1.10$ & $74.11 \pm 1.02$ & $73.72 \pm 1.11$ & $73.87 \pm 0.75$ \\
Hemicellulose & $83.41 \pm 0.29$ & $83.07 \pm 0.36$ & $83.29 \pm 0.13$ & $83.05 \pm 0.15$ \\
\hline
\end{tabular}

Note: $\mathrm{DM}=$ dry matter; $\mathrm{CF}=$ crude fiber; $\mathrm{EE}=$ ether extract; $\mathrm{CP}=$ crude protein; $\mathrm{ADF}=$ acid detergent fiber; $\mathrm{NDF}=$ neutral detergent fiber; $\mathrm{P}_{0}=$ treatment of $0 \%$ Coleus amboinicus L. leaf (CAL); $\mathrm{P}_{1}=$ treatment of $2 \%$ powdered CAL; $\mathrm{P}_{2}=$ treatment of $2 \%$ ethanol-extracted CAL; $\mathrm{P}_{3}=$ treatment of $2 \%$ waterextracted CAL.

Table 4. The milk yields, chemical composition, and specific gravity of Ettawa crossbreed goats fed with extracted Coleus amboinicus L. leaf diet in ration

\begin{tabular}{lcccc}
\hline \multirow{2}{*}{ Variables } & \multicolumn{3}{c}{ Treatments } \\
\cline { 2 - 5 } & $\mathrm{P}_{0}$ & $\mathrm{P}_{1}$ & $\mathrm{P}_{2}$ & $\mathrm{P}_{3}$ \\
\hline Milk yields (g/d) & $308.57 \pm 57.30^{\mathrm{a}}$ & $401.87 \pm 79.52^{\mathrm{b}}$ & $347.23 \pm 66.83^{\mathrm{c}}$ & $312.90 \pm 73.36^{\mathrm{a}}$ \\
Milk protein (\%) & $3.86 \pm 0.35^{\mathrm{a}}$ & $3.71 \pm 0.31^{\mathrm{a}}$ & $3.71 \pm 0.27^{\mathrm{a}}$ & $4.47 \pm 0.34^{\mathrm{b}}$ \\
Milk casein (\%) & $3.44 \pm 0.31^{\mathrm{a}}$ & $3.30 \pm 0.28^{\mathrm{a}}$ & $3.29 \pm 1.25^{\mathrm{a}}$ & $3.99 \pm 0.30^{\mathrm{b}}$ \\
Milk fat (\%) & $3.70 \pm 0.16$ & $3.68 \pm 0.19$ & $3.50 \pm 0.08$ & $3.85 \pm 0.51$ \\
Milk DM (\%) & $8.50 \pm 1.00^{\mathrm{A}}$ & $8.10 \pm 0.01^{\mathrm{A}}$ & $10.25 \pm 1.04^{\mathrm{B}}$ & $10.37 \pm 0.48^{\mathrm{B}}$ \\
SNF (\%) & $4.809 \pm 1.01^{\mathrm{A}}$ & $4.33 \pm 1.19^{\mathrm{A}}$ & $6.75 \pm 1.03^{\mathrm{B}}$ & $6.53 \pm 0.55^{\mathrm{B}}$ \\
Specific gravity & $1.0283 \pm 0.01$ & $1.0290 \pm 0.01$ & $1.0287 \pm 0.01$ & $1.0294 \pm 0.01$ \\
\hline
\end{tabular}

Note: Means in the same row with different superscripts differ significantly $(\mathrm{p}<0.05)$; Means in the same row with different capital superscripts differ significantly $(\mathrm{p}<0.01) ; \mathrm{DM}=$ dry matter; $\mathrm{SNF}=$ solids non fat; $\mathrm{P}_{0}=$ treatment of $0 \%$ Coleus amboinicus $\mathrm{L}$. leaf $(\mathrm{CAL}) ; \mathrm{P}_{1}=$ treatment of $2 \%$ powdered CAL; $\mathrm{P}_{2}=$ treatment of $2 \%$ ethanol-extracted CAL; $\mathrm{P}_{3}=$ treatment of $2 \%$ water-extracted CAL.

\section{DISCUSSION}

\section{Intake}

As shown in Table 2, the intakes of DM, OM, CP, $\mathrm{EE}, \mathrm{CF}, \mathrm{Ca}, \mathrm{P}$, and energy of experimental goats in the four treatments were not different. These results might be because each experimental goat was fed with the same ration with the same characteristics and composition. The experimental goats were maintained in the same environmental conditions. Indeed, McDonald et al. (1995) reported that factors affecting feed intake are feed characteristics and environmental conditions. Sebata \& Ndlovu (2010) added that morphology and phenology of browsing usually influence herbivores' forage selection and intake. Apart from this condition, each experimental goat was fed with $80 \%$ full daily intake with the same ration except for the content of CAL extract. The concentrate, tofu waste, and extracted CAL levels were completely given during the morning feeding to reduce the remaining feed. After concentrate feeding, forage was chopped into 5-cm-long pieces and then fed to goats. Therefore, the remaining feed was much less than the morning feed. In addition, all experimental goats were located in the same environmental condition. Consequently, the intake of each nutrient was not different among the four treatment groups.

The DM intake from this experiment is higher than the results reported previously. Badarina et al. (2015) reported that the range of DM intake was $1.44-1.56 \mathrm{~kg} / \mathrm{d}$. 
The ration provided in this experiment was over-sufficiency of goat requirement according to the standard of NRC (1981). In addition, the experimental goats were younger than the goats used by Badarina et al. (2015). The effect of treatment groups is not significant on the DM intake of the experimental goats because they were fed with the same DM composition and possibly because they are all in the same breed.

The OM intake in this experiment is lower than the results reported by Suryanindyah \& Astuti (2012); the OM intakes for that study were $1561.8 \pm 17.8$ and 1496.7 $\pm 25.6 \mathrm{~g}$. This difference might be due to the goats fed different rations. The lack of difference in OM intake among the groups in this study might be related to the same ration fed to the experimental goats, except for the amount of CAL, which comprises a small portion of the feed. Therefore, the ration likely also has the same nutrient composition, appearance, taste, and palatability. Decruyenaere et al. (2009) report that feed intake in the animal is affected by nutrient composition, physical appearance, flavor (taste and smell), and texture.

The CP intake in this experiment is relatively higher than those reported by Supriyati et al. (2016) (148-157 g/d) and by Astuti et al. (2019) (129.33-132.08 $\mathrm{g} / \mathrm{d})$ for post-weaning EC goats. In this study, the different intakes of CP might be due to the different rations consumed, weight, and age of goats, although the breed was the same with the two previous studies. The age of goat might physiologically affect the intake of CP. This difference might be due to the carvacrol content of the ration due to the CAL treatment. Carvacrol might reduce the rate of amino acid deamination and $\mathrm{CP}$ degradation in the rumen. Foskolos et al. (2016) reported that carvacrol inhibited deamination. These phenomena likely increase post-rumen CP absorption and could also increase DM and OM digestibility (Salem et al., 2015). Moreover, previous studies have shown that feed intake increases when there is more undegradable protein in the ration (Kholif et al., 2014, 2016).

The EE intake parameters were almost the same among the four treatments and relatively higher than the previous results reported by Astuti et al. (2019) (20.34-57.35 g/d) and by Supriyati et al. (2016) (34.83$35.47 \mathrm{~g} / \mathrm{d}$ ). The effect of CAL treatments in the ration is not clear on the intake of EE because the goats were exactly fed the same content of EE in the ration. In the present study, there was no effect of treatment of CAL in the ration. However, compared with the previously mentioned studies, CAL increased the EE intake due to the elevated ruminal degradation. In addition, the differences in EE intake might be due to the different types of feed consumed by the experimental goats in these experiments.

The CF intake in the present study was higher than those previously reported by Astuti et al. (2019), i.e., 78.20-88.82 g/d for post-weaning EC goats. This difference might be due to the age and body weight difference in the experimental goats in this study compared with those in the study of Astuti et al. (2019). The fiber in the ration would influence the composition of milk fat and, therefore, the composition of CF in the ration also influences other nutrients.
The Ca intake in the present study was lower compared with those reported by previous studies due to the low $\mathrm{Ca}$ concentration in this leaf. This might be possibly due to the low content of $\mathrm{Ca}$ in this leaf. Wadikar \& Patki (2016) mentioned that the content of Ca within CAL was relatively low, around $2.08 \mathrm{~g} / \mathrm{kg}$. Ganai et al. (2017) reported that the Ca intake in EC goat was between 14.86 and $22.38 \mathrm{~g} / \mathrm{d}$, while Muscher et al. (2011) mentioned that $\mathrm{Ca}$ intake in male White Saanen goats was between 7.4 and $7.7 \mathrm{~g} / \mathrm{d}$. Ca is a crucial element during lactation, and $\mathrm{Ca}$ deficiency in the ration could cause paralysis in a goat mother. The P intake was higher than that reported by Ganai et al. (2017), i.e., 7.92-8.20 g/d. Muscher et al. (2011) reported that the P intake in female White Saanen goats was between 3.25 and $3.33 \mathrm{~g} / \mathrm{d}$. P intake is affected by the composition of the ration.

\section{Digestibility}

The nutrient digestibility was also similar among all treatment groups (Table 3). This outcome might be caused by the reality that all experimental goats received the same nutrient components in their diets and are the same breed. The effect of CAL extract was not significant in this study because it comprised only a small portion of the ration. This leaf extract could influence or inhibit the deamination process within the rumen. Consequently, degradation or fermentation of nutrients by microbes in the rumen were likely similar among all groups. Hasmawati \& Hasnaeni (2016) state that nutrient digestibility depends on the fiber composition and anti-nutritional substances in the whole ration fed. These factors would also influence the microbial activity within the rumen and nutrient degradation. On the other hand, Suksombat et al. (2017) mentioned that the use of essential oil in the ration could increase the degradability of DM and NDF but not ADF and CP.

The effect of CAL extract in the ration might influence protein ammonization in the rumen. This could increase the amount of undegradable protein absorbed, increase the OM digestibility, and impact the DM digestibility. CAL extract contains carvacrol, which delays protein deamination in the rumen (Mbiriri et al., 2015) and has antimicrobial activity (Fang et al., 2019). These effects allow more OM to pass through the rumen that will be digested and absorbed in the hind gut. Garcia (2007) stated that using $250 \mathrm{mg} / \mathrm{L}$ and $500 \mathrm{mg} / \mathrm{L}$ carvacrol in the ration could reduce protein degradation by $51.5 \%$ and $72.8 \%$. The effect of carvacrol could be seen from days 3 to 9 with the indicator of increasing methane production (Mbiriri et al., 2015). However, CastañedaCorrea (2018) reported that the combination of carvacrol and thymol decreased methane production.

The DM digestibility of the experimental ration was not different among the four treatment groups. These values are higher than those reported by Arief et al. (2016); those authors reported DM digestibility of about $40 \%$. The differences in DM digestibility might be due to the differences in the ration compositions and the effect of different active compounds contents (that reduced amino acid deamination and protein degradation) within CAL in the whole ration, as was hypothesized by 
Khamisabadi et al. (2016). Salem et al. (2015) mentioned that these changes would allow the increased absorption of protein and also directly increase DM digestibility.

The ADF, NDF, and hemicellulose digestibility did not differ among the four treatments. However, Kim et al. (2019) state that the use of CAL essential oil tends to increase the digestibility of fiber without affecting VFA production. This outcome might be caused by the reality that all goats received the same amount of fiber in their rations, so the effect of CAL on fiber digestibility was not significant. It is also possible that carvacrol within CAL only influences the degradation of protein rather than fiber, as was postulated by Khamisabadi et al. (2016).

\section{Milk Yield and Quality}

The treatments significantly influenced the milk yield $(\mathrm{p}<0.05) . \mathrm{P}_{1}$ treatment provided the highest milk yield among the treatments. $P_{2}$ treatment had a higher milk yield than treatments $\mathrm{P}_{0}$ and $\mathrm{P}_{3}(\mathrm{p}<0.05)$, and treatment $P_{0}$ was not different from treatment $P_{3}(p>0.05)$ in milk yield. It might be possible that carvacrol in the CAL could indirectly increase the milk yield and stimulate the udder to produce more milk. Benchaar (2020) states that carvacrol functions as rumen fermentation modifier by its antimicrobial properties. This condition would reduce protein degradation and ammonia production in the rumen (Benchaar, 2020); therefore, it increases undegradable protein to pass through the hindgut. Carvacrol in ration also improves reproductive performance in dairy cows (Pinedo et al., 2015). However, to the best of our knowledge, there is no information concerning the transfer of carvacrol into the milk. Silva et al. (2020) concluded in their study that the supplementation of capsaicin, carvacrol, cinnamaldehyde, and eugenol could reduce DMI and increase milk yield. Xu-dong et al. (2012) state that CAL contains phytochemical components, such as polyphenols, tannins, and alkaloids, having capacities to increase milk yields. Moreover, the regular addition of flavonoids to the ration could increase prolactin secretion, hormone stimulating the mammary gland cells to synthesize and produce milk. Fati et al. (2014) reported that CAL could increase milk yields up to $10 \%$. Hutajulu \& Junaidi (2013) add that CAL contains thymol, forskolin, and carvacrol, which may stimulate milk synthesis that eventually increases milk yield. Yanza et al. (2018) also report that bioactive components can modify the ruminal microbial fermentation and modulate methanogenesis and biohydrogenation of fatty acids. For example, some active compounds such as phenolics, saponins, tannins, flavonoids, carvacrol, and other essential oils inhibit methanogenesis within the rumen. This condition could reduce methane emission from rumen and simultaneously improve livestock productivity (Patra \& Saxena, 2010).

Related to this experiment, $\mathrm{P}_{1}$ and $\mathrm{P}_{2}$ treatments produce higher milk yields than $P_{3}$ treatment. This effect might be possibly due to the treatment's effects on the supply of carvacrol and other active compounds as rumen modifiers in the rumen. $\mathrm{P}_{1}$ treatment could pos- sibly supply the highest level of carvacrol among four treatments as it was CAL powder that fully contains carvacrol and other active compounds. The supply of carvacrol in the rumen was then followed by $\mathrm{P}_{2}$ and $\mathrm{P}_{3}$ treatments. We assume that ethanol extract, as in $\mathrm{P}_{2}$ treatment, contain higher level of carvacrol than water extract, as in $\mathrm{P}_{3}$ treatment, while $\mathrm{P}_{0}$ treatment as a control does not have carvacrol. Therefore, these treatments would possibly influence the milk yield. Apart from this condition, other factors such as parity and stage of lactation (DeVries et al., 2011) also influence milk yield. Unfortunately, this information was not available in this study.

The addition of CAL extracted in the ration significantly $(p<0.05)$ increased the milk protein content. $\mathrm{P}_{3}$ treatment showed the highest milk protein content of $4.47 \%$. This highest value is also higher than those reported by Dharmawan et al. (2019), with milk protein contents between $3.09 \%$ and $3.58 \%$. However, the digestibility of nutrients (Table 2 ) is relatively the same. Theoretically, milk protein was synthesized by using amino acid from the blood (Rhoads \& Nogalska, 2007). Supplementation of CAL water extract in the ration $\left(\mathrm{P}_{3}\right)$ might possibly influence the transport of nutrients from the blood into the cells of the mammary glands for the synthesis of milk protein. The different levels of CAL supplementation also significantly $(\mathrm{p}<0.05)$ affected the milk casein contents. This result might be related to the fact that milk casein content is related to the milk protein content; total milk protein in this study is $2.7 \%$.

$\mathrm{P}_{3}$ treatment with CAL water extracted was the best result in terms of milk protein content compared to the other treatments. This highest milk protein content might be because P3 treatment was supplementation of CAL water extract that provide carvacrol an antibacterial agent that could protect the degradation of protein in the rumen and pass it into abomasum intestine. Widyawati et al (2014) reported that water was the best solvent in extracting Pluchea indicia Less leaves. This undegradable protein was enzymatically digested to be amino acid and absorbed into the blood. This condition will increase the amino acid concentration in the blood. These amino acids would be absorbed by the mammary gland cells and will be used to synthesize milk protein such as casein, lactalbumin, and lactoglobulin.

There was no difference $(p>0.05)$ in the milk fat contents among the treatments. The average fat milk content was $3.50 \%-3.85 \%$. This range of milk fat content is similar to that reported by Rojo et al. (2015) that milk fat content ranges between $3.4 \%$ and $4.0 \%$. The milk fat content is easily changeable and depends on the fiber content of the consumed feed. Khan et al. (2015) state that there is a correlation between nutritive values of feed consumed and milk yield and quality. Low fiber content in the ration would cause low production of acetic acid in the rumen and thus reduces milk fat because acetic acid is the main component used to synthesize milk fat.

Some articles reported that the milk fat content is influenced by the nutrient content of feed fed by the animal (Frelich et al., 2012; Adler et al., 2013; Hanuš et al., 2016). The milk fat is especially affected by fiber 
content in the ration. All experimental goats were fed with the same ration with the same composition of nutrients (Table 1), with the same intake of CF (Table 2) and digestibility (Table 3). Therefore, it could possibly provide the same effect on the milk fat content of each experimental goat in which the milk fat content of the experimental goat was not different among the four treatments.

The method of CAL extraction significantly affected the composition of milk DM $(\mathrm{p}<0.01)$. These results are lower than those reported by Rojo et al. (2015), with a range of DM content between $10.4 \%-11.4 \%$.

The solvent used for CAL extraction did not significantly affect $(p>0.05)$ SG of the milk. The average SG of the milk samples was 1.0288, which is a little bit lower than the value reported by Harjanti et al. (2017) at one day post-partum (1.041) and two days post-partum (1.034) for EC goats. While Tesfay et al. (2015) reported that the SG of pasteurized milk was 1.031 and SG of milk taken from a vendor was 1.025. The SG of milk found in the present experiment was also lower than those found by Basitan \& Jarcia (2013), who conducted the study of the SG of milk goat fed with Malunggay (Moringa oleifera).

Milk SG in this experiment was somewhat difficult to explain. In fact, SG was relatively similar with the milk fat content, while DM, casein protein, and SNF composition were significantly different among four treatments. Generally, SG is influenced by the milk composition of DM, CP, fat, SNF, and CF. Partially, SG in this study could be affected by the same chemical composition of ration, the similar digestibility of ration, and the relatively similar content of milk fat for all treatments. This statement could be related to the result of Şahan et al. (2005) that the variations influenced SG of milk in Awasi ewes in Turkey in fat content. On the other hand, contrary to the results of other parameters in which nutrient composition of milk such as DM, protein, and casein were different among four treatments. Other possibilities, SG could also be affected by the parity and the stage of lactation of experimental goats, the environment temperature, and the gas evaporation from milk. William et al. (2012) stated that SG and milk composition such as milk protein, lactose, fat, solid nonfat, and total solid except ash was affected by the stage of lactation and parity in the case of West African Dwarf sheep. Unfortunately, there was no data on parity, the stage of lactation, and environmental temperature in this study. Apart from this, evaporation of $\mathrm{CO}_{2}$ and $\mathrm{N}_{2}$ gases also influences SG during the milking process (Rosatio et al., 2015).

\section{CONCLUSION}

Supplementation of $2 \%$ CAL powder in the ration for EC goats improved milk yield by $30.24 \%$ compared with the control ration. The supplementation of CAL $2 \%$ water extract in the ration improved the quality of milk in terms of DM, protein, casein, fat, and SNF.

\section{CONFLICT OF INTEREST}

The authors declare that there is no conflict of interest with any financial, personal, or other relationships with other people or organization related to the material discussed in the manuscript.

\section{ACKNOWLEDGEMENT}

This project was fully funded by University of Jambi with the contract number B/1594/UN21.18/ PT.01.03/2019 Dated 17 May 2019.

\section{REFERENCES}

Acharya, I. P., D. J. Schingoethe, K. F. Kalscheur, \& D. P. Casper. 2015. Response of lactating dairy cows to dietary protein from canola meal or distillers' grains on dry matter intake, milk production, milk composition, and amino acid status. Can. J. Anim. Sci. 95: 267-279. https://doi. org/10.4141/cjas-2014-130

Adler, S.A., S.K. Jensen, E. Govasmark, \& H. Steinshamn. 2013. Effect of short-term versus long-term grassland management and seasonal variation in organic and conventional dairy farming on the composition of bulk tank milk. J. Dairy Sci. 96: 5793-5810. https://doi.org/10.3168/ jds.2012-5765

Adriani., R. Asra, S. Novianti, \& Fatati. 2019. The effect of Coleus amboinicus L supplementation on in vitro digestibility. Pak. J. Nutr. 18: 241-246. https://doi.org/10.3923/ pjn.2019.241.246

Ahirwar, P. \& M. Tembhre. 2016. Hepatoprotective efficacy of coleus amboinicus leaf extract on carbon tetrachloride induced liver damage in rats. Asian J. Exp. Sci. 30: 45-50.

AOAC. 1990. Official Methods of Analysis of AOAC International. 15th ed Assoc. Off. Anal. Chem. Arlington.

Arief, Rusdimansyah, S. Sowmen, R. Pazla, \& Rizqan. 2020. Milk production and quality of Etawa crossbreed dairy goat that given Tithonia diversifolia, corn waste and concentrate based palm kernel cake. Biodiversitas 21: 4004-4009. https://doi.org/10.13057/biodiv/d210910

Arief, N. Jamarun, \& B. Satria. 2016. Characteristics of Ettawa crossbred dairy goat rumen fluid and digestibility of palm oil industry by-product. Pak. J. Nutr. 15: 28-32. https://doi. org/10.3923/pjn.2016.28.32

Astuti, D. A., A. Anggraeny, L. Khotijah, S. Suharti, \& A. Jayanegara. 2019. Performance, physiological status, and rumen fermentation profiles of pre- and post-weaning goat kids fed cricket meal as a protein source. Trop. Anim. Sci. J. 42: 145-151. https://doi.org/10.5398/tasj.2019.42.2.145

Badarina, I., D. Evvyernie, T. Toharmat, E. N. Herliyana, \& L. K. Darusman. 2015. Digestibility, milk production, and udder health of etawah goats fed with fermented coffee husk. Med. Pet. 38: 42-47. https://doi.org/10.5398/ medpet.2015.38.1.42

Basitan, I. S. \& E. G. Jarcia. 2014. Yield, quality and feed cost efficiency of milk produced by anglo-nubian goats fed different mixtures of napier (Pennisetum purpureum) grass and malunggay (Moringa oleifera). Philippine Journal of Veterinary and Animal Sciences 39: 193-200.

Benchaar, C. 2020. Feeding oregano oil and its main component carvacrol does not affect ruminal fermentation, nutrient utilization, methane emissions, milk production, or milk fatty acid composition of dairy cows. Journal of Dairy Science 103: 1516-1527. https://doi.org/10.3168/ jds.2019-17230 
Castañeda-Correa, A., A. Corral-Luna, M. E. Hume, R. C. Anderson, O. Ruiz-Barrera, Y Castillo-Castillo, F. R. Almeida, J. Salinas-Chavira, \& C.Arzola-Alvarez. 2018. Effects of thymol and carvacrol, alone or in combination, on fermentation and microbial diversity during invitro culture of bovine rumen microbes. J. Env. Sci. Health, Part B 54:1-6. https://doi.org/10.1080/03601234.2018.1536580

Damanik, R. 2009. Torbangun (Coleus amboinicus Lour): A Bataknese traditional cuisine perceived as lactagogue by Bataknese lactating women in Simalungun, North Sumatera, Indonesia. Journal of Human Lactation 25:6472. https://doi.org/10.1177/0890334408326086

Decruyenaere, V., A. Buldgen, \& D. Stilmant. 2009. Focus on: Factors affecting intake by grazing ruminants and related quantification methods: A review. Biotechnol. Agron. Soc. Environ. 13:559-573.

DeVries, T. J., L. Holtshausen, M. Oba, \& K. A. Beauchemin. 2011. Effect of parity and stage of lactation on feed sorting behavior of lactating dairy cows. J. Dairy Sci. 94:4039-4045. https://doi.org/10.3168/jds.2011-4264

Dharmawan, R., P. Surjowardojo, \& T. E. Susilorini. 2019. Effect of steaming up by gliricidiasepiumto dairy goats in late gestation on milk yield and composition during the early lactation. Int. J. Adv. Res. Sci. Eng. Technol. 4: 290-293.

Djoković, R., M. Cincović, B. Belić, B. Toholj, I. Davidov, \& T. Hristovska. 2015. Relationship between blood metabolic hormones, metabolites and energy balance in Simmental dairy cows during peripartum period and lactation. Pak. Vet. J. 35:163-167.

Fang, Q. Z., Y. Hu, F. Liu, J. Mei, \& J. Xie. 2019. Antimicrobial carvacrol incorporated in flaxseed gum-sodium alginate active films to improve the quality attributes of chinese sea bass (lateolabrax maculatus) during cold storage. Molecules 24: 3292. https://doi.org/10.3390/molecules24183292

Fati, N., I. Irda, \& D. Syukriani. 2014. Using of bangun-bangun leafs (Coleusamboinicus, 1) on red sugar block to upgrading milk production of Frisian Holstein. Int. J. Adv. Sci. Eng. Inf. Tech. 4:48-50. https://doi.org/10.18517/ijaseit.4.2.374

Frelich, J., M. Šlachta, O. Hanuš, J. Špička, E. Samková, A. Weglarz, \& P. Zapletal. 2012. Seasonal variation in fatty acid composition of cow milk in relation to the feeding system. Anim. Sci. Pap. Rep. 30: 219-229.

Foskolos, A., S. Cavini, A. Ferret, \& S. Calsamiglia. 2016 Effects of essential oil compounds addition on ryegrass silage protein degradation. Can. J. Anim. Sci. 96: 100-103. https://doi. org/10.1139/cjas-2015-0025

Ganai, I. A., A. Rastogi, R.K. Sharma, H. Kumar, \& S. Ali. 2017. Evaluation of effect of combined feeding of wheat and paddy straw on calcium and phosphorus in goats. J. Entomol. Zool. Stud. 5:1706-1709. https://doi.org/10.17582/ journal.jahp/2017/5.3.97.102

Garcia, V. 2007. Potential of carvacrol to modify in vitro rumen fermentation as compared with monensin. Cambridge J. 1: 675-680. https://doi.org/10.1017/S1751731107730781

Gerber, N. 1960. Practical Treaty for The Analysis of Milk and For the Control of Dairy Product. 11th ed Editorial Dossat. Madrid, Spain.

Hanuš, O., L. Křížová, E. Samková, J. Špička, J. Kučera, M. Klimešová, P. Roubal, \& R. Jedelská. 2016.The effect of cattle breed, season and type of diet on the fatty acid profile of raw milk. Arch. Anim. Breed 59: 373-380. https://doi. org/10.5194/aab-59-373-2016

Harjanti, D. W., R. Ciptaningtyas, A. N. Al-Baarri, \& E. Kusumanti. 2017. Isolation and identification of lactoferrin and lactoperoxidase from the colostrum of indonesianettawa crossbred goat. Adv. Sci. Letters 23: 3321-3324. https:// doi.org/10.1166/asl.2017.9114

Haro, A. N., M. D. Carro, T. Evan, \& J. González. 2018. Protecting protein against ruminal degradation could contribute to reduced methane production. J. Anim. Physiol. Anim. Nutr. 102:1482-1487. https://doi.org/10.1111/jpn.12973

Hasmawati \& Husnaeni. 2016. Dry matter digestibility and natural organic matter mulberry feed gamal leaves on male goat crossbreed ettawa. Chalaza J. Anim. Husb.1: 42-46. https://doi.org/10.31327/chalaza.v1i2.182

Hutajulu, T. F. \& L. Junaidi. 2013. The benefif of bangun-bangun leaves (Coleus amboinicus 1.) for increasing of rat breast milk production. J. Riset Industri. 7:15-24.

Kent, J.C., K. P. Danielle, \& P. G. Catherine. 2012. Principles for maintaining or increasing breast milk production. J. Obstet. Gynecol. Neonatal Nurs. 41:114-121. https://doi. org/10.1111/j.1552-6909.2011.01313.x

Khamisabadi, H., F. Kafilzadeh, \& B. Charaien. 2016. Effect of thyme (Thymus vulgaris) or peppermint (Mentha piperita) on performance, digestibility and blood metabolites of fattening Sanjabi lambs. Biharean Biol. 10:118-122.

Khan, N. A., P. Yu, M. Ali, J. W. Cone, \& W. H. Hendriks. 2015. Nutritive value of maize silage in relation to dairy cow performance and milk quality. J. Sci. Food Agr. 95: 238252. https://doi.org/10.1002/jsfa.6703

Kholif, A.E., T.A. Morsy, G.A. Gouda, U.Y. Anele, \& M.L. Galyean. 2016. Effect of feeding diets with processed Moringaoleifera meal as protein source in lactating AngloNubian goats. Anim. Feed Sci. Technol. 217: 45-55. https:// doi.org/10.1016/j.anifeedsci.2016.04.012

Kholif, A.E., H.M. Khattab, A. A. El-Shewy, A. Z. M. Salem, A.M. Kholif, M. M. El-Sayed, H. M. Gado, \& M. D. Mariezcurrena. 2014. Nutrient digestibility, ruminal fermentation activities, serum parameters and milk production and composition of lactating goats fed diets containing rice straw treated with Pleurotusostreatus. Asian-Australas. J. Anim. Sci. 27:357-364. https://doi. org/10.5713/ajas.2013.13405

Kim, H., E. Jung, H. G. Lee, B. Kim, S. Cho, S. Lee, I. Kwon, \& J. Seo. 2019. Essential oil mixture on rumen fermentation and microbial community - an in vitro study. AsianAustralas. J. Anim. Sci. 32:808-814. https://doi.org/10.5713/ ajas.18.0652

Laila, F., D. Fardiaz, N. D. Yuliana, M. R. M. Damanik, \& F. N. Annisa. 2020. Dewi methanol extract of Coleus amboinicus (lour) exibited antiproliferative activity and induced programmed cell death in colon cancer cell widr. Hindawi Int. J. Food Sci. 2020, Article ID 9068326, 12. https://doi. org/10.1155/2020/9068326

Marwah, M. P., Y. Y. Suranindyah, \& T. W. Murti. 2010. Milk production and milk composition of ettawa crossbred goat, fed katu leaves (Sauropus androgynus (1.) Merr) as supplementation during early lactation. Bul. Anim. Husb. 34:94102. https://doi.org/10.21059/buletinpeternak.v34i2.95

Mbiriri, D.T., S. Cho., C. I. Mamvura, \& N. J. Choi. 2015. Assessment of rumen microbial adaptation to garlic oil, carvacrol and thymol using the consecutive batch culture system. J. Vet. Sci. Anim. Husb. 3: 401.

McDonald, M., P. Edwards., J.F.D. Greenhalgh, \& C.A. Morgan. 1995. Animal Nutrition. Longman, London, UK.

Monica, M., M. Beatrice, M. Anselimo, \& M. Simon. 2014. Factors affecting kenya alpine dairy goat milk production in nyeri region. J. Food Res. 3:160-167. https://doi. org/10.5539/jfr.v3n6p160

Muscher, A. S., M. Piechotta, G. Breves, \& K. Huber. 2011. Modulation of electrolyte homeostasis by dietary nitrogen intake in growing goats. Br. J. Ntr. 105:1619-1626. https:// doi.org/10.1017/S0007114510005350

NRC. 1981. Nutrient Requirements of Goats: Angora, Dairy, And Meat Goats in Temperate and Tropical Countries. National Academy of Sciences, National Academic Press, Washington, DC. 
Patra, A. K. \& J. Saxena. 2010. A new perspective on the use of plant secondary metabolites to inhibit methanogenesis in the rumen. Phytochemistry 71:1198-1222. https://doi. org/10.1016/j.phytochem.2010.05.010

Pinedo, P. J, J. S. Velez, H. Bothe, D. Merchan, J. M. Pineiro, \& C. A. Risco. 2015. Effect of intrauterine infusion of an organic-certified product on uterine health, survival, and fertility of dairy cows with toxic puerperal metritis. J. Dairy Sci. 98:3120-3132. https://doi.org/10.3168/jds.2014-8944

Resthu, M., D. Araby, \& S. Wahyuni. 2019. The effects of the oxytocin hormone induction on the value of the composition of Etawah crossbred goat milk. J. Anim. Prod. 21:122128. https://doi.org/10.20884/1.jap.2019.21.3.705

Rhoads, R. E. \& E. G. Nogalska. 2007. Translational regulation of milk protein synthesis at secretory activation. J. Mammary Gland Biol. Neoplasia 12:283-292. https://doi. org/10.1007/s10911-007-9058-0

Rojo, R., A. Kholif, A. Salem, M. Elghandour, N. Odongo, R. M. D. Oca, \& M. Alonso. 2015. Influence of cellulase addition to dairy goat diets on digestion and fermentation, milk production and fatty acid content. J. Agr. Sci. 153:1514-1523. https://doi.org/10.1017/S0021859615000775

Rowland, S.J. 1938. The pecipitation of the protein of milk 1. Casein, II. Total protein III. Globulin. IV. Albumin and Protease-peptone. J. Dairy Res. 9:30. https://doi. org/10.1017/S0022029900002284

Şahan, N., D. Say, \& A. Kaçar. 2005 Changes in chemical and mineral contents of awassi ewes' milk during lactation. Turk. J. Vet. Anim. Sci 29: 589-593

Salem, A. Z. M., H. Alsersy, L.M. Camacho, M.M. El-Adawy, M.M.Y. Elghandour, A.E. Kholif, N. Rivero, M.U. Alonso, \& A. Zaragoza. 2015. Feed intake, nutrient digestibility, nitrogen utilization, and ruminal fermentation activities in sheep fed Atriplexhalimus ensiled with three developed enzyme cocktails. Czech J. Anim. Sci. 60:185-194. https:// doi.org/10.17221/8133-CJAS

SAS. 2002. SAS 9.1.3 Portable. SAS 9.1 for Windows, SAS Institute Inc, Cory 27513 USA.

Sebata, A. \& L. R. Ndlovu. 2010. Effect of leave size, thorn density and leaf accessibility on instantaneous intake rates of five woody species browsed by Matebele goats (Capra hircus L) in a semi-arid savanna, Zimbabwe. J Arid Environ 74: 1281-1286. https://doi.org/10.1016/j.jaridenv.2010.05.028

Silva, R. B. D., M. N. Pereira., R. C. D. Araujo., W. D. R. Silva, \& R. A. N. Pereira. 2020. A blend of essential oils improved feed efficiency and affected ruminal and systemic variables of dairy cows. Transl. Anim. Sci. 4:182-193. https:// doi.org/10.1093/tas/txz183

Suksombat, W., A. Nanon, C. Meeprom, \& P. Lounglawan. 2017. Feed degradability, rumen fermentation and blood metabolites in response to essential oil addition to fistulated non-lactating dairy cow diets. Anim. Sci. J. 88: 13461351. https://doi.org/10.1111/asj.12778
Supriyati., I. G. M. Budiarsana, L. Praharani, R. Krisnan, \& I. K. Sutama. 2016. Effect of choline chloride supplementation on milk production and milk composition of Etawah grade goats. J. Anim. Sci. Technol. 58:30. https://doi.org/10.1186/ s40781-016-0113-5

Suranindyah, Y. \& A. Astuti. 2012. The effects of feeding dried fermentedcassava peel on milk production and composition of etawah crossed bred goat. International Journal of Nutrition and Food Engineering 6: 911-914.

Tesfay, T., A. Kebede, \& E. Seifu. 2015. Physico chemical properties of cow milk produced and marketed in dire dawa town, eastern ethiopia. Food Sci. Qual. Manag. 42:56-61.

Turkyılmaz, C., E. Onal, I. M. Hirfanoglu, O. Turan, E. Koç, E. Ergenekon, \& Y. Atalay. 2011. The effect of galactagogue herbal tea on breast milk production and short-term catch-up of birth weight in the first week of life. J. Altern Complement Med. 17:139-142. https://doi.org/10.1089/ acm. 2010.0090

Van Soest, P.J. 1963. Use of detergents in the analysis of fibrous feeds. II A rapid method for the determination of fiber and lignin. J. Assoc. Offic. Anal. Chem. 46: 829. https://doi. org/10.1093/jaoac/46.5.829

Wadikar, D. D. \& P. E. Patki. 2016. Coleus aromaticus: a therapeutic herb with multiple potentials. J. Food Sci. Technol. 53:2895-2901. https://doi.org/10.1007/s13197-016-2292-y

Widyawati, P., S., T. D. W. Budianta, F. A. Kusuma, \& E. L. Wijaya. 2014. Difference of solvent polarity to phytochemical content and antioxidant activity of Pluchea indicia Less leaves extracts. Int. J. Pharmacognosy and Phytochemical Research 6: 850-855.

Williams, T.J., I.J. James, M.R. Abdulateef, L.O. Onabegun, S.O. Jinadu, Y.O. Falade, F.T. Solola, O.O. Adewumi, \& O.E. Oke. 2012. Composition and specific gravity of milk of West African Dwarf sheep as affected by stage of lactation and parity. Nigerian Journal of Animal Production 39: 49-56. https://doi.org/10.51791/njap.v39i2.838

Xu-dong G., D.Qiyu, W. Yue-ying, T. Yan,D. Kai-dong, W. Xin-jian, F. Tong, \& Y. Gui-long. 2012. The effect of administration of ritun on plasma levels of estrogen prolactin growth hormone and gene expression of their receptors in mammary glands in ovariectomizes rats. J. Integr. Agric. 11:1700-1706. https://doi.org/10.1016/ S2095-3119(12)60173-7

Yanza, Y. R., M. Szumacher-Strabel, M. Bryszak, M. Gao, P. Kolodziejski, A. Stochmal, S. Slusarczyk, A. K. Patra, \& A. Cieslak. 2018. Coleus amboinicus (Lour.) leaves as a modulator of ruminal methanogenesis and biohydrogenation in vitro. J. Anim. Sci. 96:4868-4881. https://doi.org/10.1093/ jas/sky321

Zamiri, M. J., E. A. Abadi, E, Z. Momeni, M. R.Rezvani, H. Atashi, \& A. Akhlaghi. 2015. Effect of thymol and carvacrol on nutrient digestibility in rams fed high or low concentrate diets. Iranian J. Vet. Res. 16:335-340. 